\title{
Examining the relationships between willingness to communicate in English, communication confidence, and classroom environment
}

Ghonsooly, Behzad

Ferdowsi University of Mashhad,Iran (Ghonsooly@yahoo.com)

Hosseini Fatemi, Azar

Ferdowsi University of Mashhad, Iran (azar.h.fatemi@gmail.com)

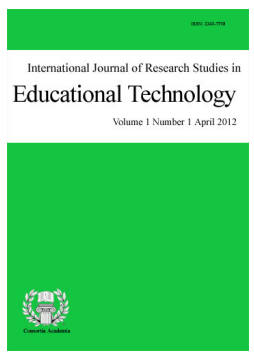

ISSN: $2243-7738$ Online ISSN: 2243-7746

OPEN ACCESS

Khajavy, Gholam Hassan $\gtrsim$

Ferdowsi University of Mashhad, Iran (Hasan.khajavi@gmail.com)

\section{Abstract}

The purpose of the present study is to examine the Iranian EFL learners' level of willingness to communicate in English, and the relationships between willingness to communicate, communication confidence, and classroom environment. For this purpose, 243 Iranian EFL learners participated in this study. Results of the descriptive statistics indicated that participants were moderately willing to communicate in English inside the language classroom, felt low levels of anxiety, and perceived themselves moderately confident to communicate in English in the classroom. Correlational analyses also indicated that willingness to communicate is positively correlated with classroom environment and perceived communicative competence, and negatively correlated with communication anxiety.

Keywords: willingness to communicate; perceived communicative competence; communication anxiety; classroom environment 


\section{Examining the relationships between willingness to communicate in English, communication confidence, and classroom environment}

\section{Introduction}

The importance of communication for developing English proficiency has been emphasized in current approaches toward language teaching. According to MacIntyre \& Charos (1996), if language learners do not use language in the classroom, they cannot become proficient. Recently, a new construct called willingness to communicate (WTC) has been proposed to examine the students' tendency toward communication in a second or foreign language (L2). WTC was originally proposed with regard to first language by McCroskey \& Baer (1985). In the first language, it is considered as a personality trait which does not change over time. However, when it comes to L2, it is quite different from L1 (MacIntyre, Clement, Dorneyi, \& Noels, 1998). The reason is that communication confidence can range from $0 \%$ to $100 \%$ in an L2, while most people have a high level of communicative competence in L1 (MacIntyre et al, 1998).

L2WTC has been defined as "a readiness to enter into discourse, at a particular time with a specific person or persons, using L2" (MacIntyre et al., 1998, p.547). In their seminal work on L2WTC, MacIntyre et al (1998) proposed a pyramid model of L2 communication in which different variables that affect L2WTC has been described. After proposing this model, many studies have been conducted in different contexts to explore L2WTC (Yashima, 2002; Kim, 2004; Cetinkaya, 2005; Peng \& Woodrow, 2010; Ghonsooly, Khajavy, \& Asadpour, 2012). Recently, the role of classroom environment as an important factor in L2WTC has been proposed by Peng and Woodrow (2010). According to them, in addition to cognitive and affective factors, environment also is a significant predictor of L2WTC. However, very few studies have examined the relationship between classroom environment and L2WTC (e.g. Peng \& Woodrow, 2010). The purpose of this study is to examine the relationships among L2WTC, communication confidence, and classroom environment.

\section{Review of the Literature}

Willingness to communicate was originally conceptualized for first language communication (McCroskey \& Richmond, 1987). It was based on the previous works on unwillingness to communicate (Burgoon, 1976), predisposition toward verbal behavior (Mortensen, Arntson, \& Lustig, 1977), and shyness (McCroskey \& Richmond, 1982). McCroskey and associates considered it as a personality trait. To answer this question that why people differ in their level of WTC, they argued that it is due to its antecedents. These antecedents of WTC include introversion-extraversion, anomie and alienation, communication competence, self-esteem, communication apprehension, and cultural diversity. By identification of these six variables, many studies were done to examine the role of these variables in WTC (MacIntyre, 1994; McCroskey \& Richmond, 1987, Sallinen-Kuparinen, McCroskey, \& Richmond, 1991).

When WTC is applied to the second/ foreign language, it is quite different. For example, Charos (1994) showed that there is a negative relationship between WTC in L1 and L2. MacIntyre et al. (1998) developed a pyramid model of L2 WTC integrating linguistic, communicative and social psychological variables. These variables include state of communicative self-confidence, desire to communicate with a specific person; self-confidence, intergroup and interpersonal motivation; communicative competence, social attitudes, intergroup attitudes; personality and intergroup climate.

Among the different predictors of the L2WTC, communication confidence and classroom environment have been the strongest predictors of it (e.g. Peng \& Woodrow, 2010; Yashima, 2002; Ghonsooly et al, 2012, Cetinkaya, 2005). Self-confidence construct proposed by Clement (1980, 1986) involves two variables: self-perceived communicative competence and a lack of language anxiety. Clement and his associates (Clement, 
1980; Clement \& Kruidenier, 1983) showed that in multilingual communities, linguistic self-confidence plays an important role in learning the language of the other community. Perceived communicative competence refers to learners' self-evaluation of their L2 skills (Peng, 2009). Research has shown that there is a significant relationship between perceived communicative competence and actual competence (MacIntyre, Noels, \& Clement, 1997). Also, it has been suggested that perceived communicative competence is a better predictor of L2 performance for two reasons. First, individuals usually choose to communicate based on their self-judgment of their L2 proficiency rather than their actual competence, as they are not aware of their actual competence (McCroskey \& Richmond, 1990). Second, as MacIntyre et al. (1997) mentioned perceived communicative competence can save both time and formal testing expenses.

The other subcomponent of L2 self-confidence is language anxiety. MacIntyre (1999) defines foreign language anxiety as "worry and negative emotional reaction aroused when learning or using a second language" (p.27). Two of the most well-known classifications are trait, state, and situation-specific (MacIntyre \& Gardner, 1991) and facilitating-debilitating views of anxiety. Trait anxiety is stable over time, while state anxiety is a transient and moment-to-moment feeling. Situation-specific anxiety is usually engendered by specific situations. Language anxiety is considered to be situation-specific, as it is closely related to L2 learning situations (Horwitz, 1986). Facilitating-debilitating view of language anxiety proposes that anxiety does not necessarily impede learning, and in some cases it could improve language performance and have a positive effect on language leaning. In other words, while debilitating anxiety has negative impact on learners' performance, facilitating anxiety can actually enhance it.

Many researchers have examined the relationship between anxiety and L2 learning since early 1970s (e.g. MacIntyre \& Gardner, 1991; Aida, 1994; MacIntyre 1999). Their findings have shown that there is a negative relationship between L2 anxiety and the level of achievement. Foreign language anxiety is common among foreign language learners (Young, 1991) and it is seen as one of the great obstacles of L2 learning and achievement. Lower achievement with higher anxiety is attributed to negative effects of anxiety on language learning (Tóth, 2007; MacIntyre, 1999, 2002; Horwitz, 2001). Mahmoodzadeh (2013) explored the role of gender and anxiety in Iranian EFL context. Results of his study indicated that mixed-gender classrooms are anxiety-provoking, due to the present of the opposite sex. Research has indicated that there is a positive relationship between perceived communicative competence and L2WTC. Also, it has been found that communication anxiety is negatively related to perceived communicative competence and L2WTC.

Based on Bronfenbrenner's ecological perspective of human development (1979), development is a joint function of person and environment. This means that in addition to cognitive and affective factors, environment is another important factor which affects an individual's development. Applied in language learning, the classroom environment is a very important factor in the process of learners' language learning. Three of the most influential factors in the language classroom include teacher support, student cohesiveness, and task orientation (Williams \& Burden, 1997; Peng \& Woodrow, 2010). Teacher support refers to the extent to which the teacher helps, supports, trusts, befriends, and is interested in students (Dorman, Fisher, \& Waldrip, 2006). Student cohesiveness refers to the extent to which students know, help and support each other (Dorman et al., 2006). Task orientation refers to the extent to which it is important to complete activities and solve the problems (Dorman et al., 2006). Attractive and useful tasks lead to student engagement. In Peng \& Woodrow's (2010) study, a negative correlation was found between communication anxiety with L2WTC, perceived communicative competence, teacher support, student cohesiveness, and task orientation. Also, a positive correlation was found between L2WTC with perceived communicative competence, teacher support, student cohesiveness, and task orientation.

The purpose of the present study is to explore students' level of L2WTC, communication confidence, and perceptions of classroom environment. Also, the relationships between L2WTC, communication confidence, and classroom environment are examined. The following research questions are answered in the present study: 
Ghonsooly, B., Hosseini Fatemi, A., \& Khajavy, G. H.

$>$ What are the Iranian EFL learners' level of L2WTC, communication confidence, and perceptions of classroom environment?

What are the relationships between L2WTC, communication confidence, and classroom environment?

\section{Methodology}

\subsection{Settings and participants}

A total of 243 undergraduate EFL university students from Ferdowsi University and Imam Reza College participated in this study, including 148 females (60.9\%), 84 males (34.6\%), and $11(4.5 \%)$ participants who did write their gender in the questionnaire. All of them were studying English language as an academic major. The range of the age of the participants was between 18 and 42, and the mean age was 21.87 ( $\mathrm{SD}=2.97)$.

\subsection{Instrumentation}

\section{WTC in English}

Ten items from Peng \& Woodrow (2010, adapted from Weaver, 2005) were used in this study to measure WTC in English (Cronbach's $\alpha=$ ). Students answered the questions on a seven point Likert scale from " $1=$ definitely not willing" to "7 = definitely willing".

\section{Communication Confidence in English}

Perceived communicative competence in English - Six items from Peng \& Woodrow (2010, adapted from Weaver, 2005) were used on an 11 point can-do scale ranging from $0 \%, 10 \%$, up to $100 \%$. Students should show the percentage of the time they feel competent to communicate in English.

Communication anxiety in English - Ten items from Horwitz et al. (1986) were used for assessing communication anxiety on a seven point Likert scale measuring the extent to which the participants feel anxious in various classroom communication situations from 1 (completely disagree) to 7 (completely agree).

\section{Classroom environment}

Thirteen items from Peng \& Woodrow (2010, adapted from Fraser, Fisher, \& McRobbie, 1996) were used for assessing classroom environment. These items measured teacher support, student cohesiveness, and task orientation on a seven point scale from 1 (completely disagree) to 7 (completely agree).

\section{Results}

Descriptive statistics including mean, standard deviation, minimum, maximum, skewness, and kurtosis were measured for all the scales. Descriptive statistics for the items of L2WTC are shown in Table 1. The respondents' scores ranged on a seven point scale. All the scores were normally distributed within the range of \pm 2.0 . As can be seen in Table 4.1, the highest and lowest mean scores on L2WTC are items 4 and 2, respectively. In other words, Iranian EFL learners were most willing to ask the teacher in English to repeat what he or she just said in English because they did not understand, while they were least willing to do a role-play standing in front of the class in English.

Also, the mean score obtained for total L2WTC was 43.52. Following Liu \& Jackson (2008) and Peng (2009), to examine the L2WTC level of the learners, it was interpreted from the ratio of the mean L2WTC score to the full score. Considering ten items on a seven point scale, full score for this scale is 70 . A total score of more than $80 \%$ of the full score, which is 56 (i.e. $70 \times 80 \%$ ) shows strong willingness to communicate; and a total score of $60 \%$ to $80 \%$ of the full score, which is between 42 and 56 , indicates moderate willingness to 
Relationships between willingness to communicate in English, confidence, and classroom environment

communicate. In the present study, the mean score (43.52) was between 42 and 56. It implies that Iranian EFL learners were moderately willing to communicate in English in their classrooms.

Table 2 shows the descriptive statistics for communication anxiety (CA). The respondents' scores ranged on a seven point scale for ten items. All the scores were normally distributed within the range of \pm 2.0 . As can be seen in Table 4.2, Iranian EFL learners experience the most communication anxiety when they have to speak English without preparation in class (item CA3), and they feel the least anxiety when they speak English in the classroom (CA8).

\section{Table 1}

Descriptive statistics for L2WTC items

\begin{tabular}{|c|c|c|c|c|c|c|}
\hline Items & Min & Max & M & SD & Skewness & Kurtosis \\
\hline WTC1 & 1.00 & 7.00 & 3.95 & 1.86 & -.01 & -.99 \\
\hline WTC2 & 1.00 & 7.00 & 3.47 & 1.83 & .24 & -.98 \\
\hline WTC3 & 1.00 & 7.00 & 4.65 & 1.62 & -.48 & -.36 \\
\hline WTC4 & 1.00 & 7.00 & 5.19 & 1.57 & -.71 & -.12 \\
\hline WTC5 & 1.00 & 7.00 & 4.68 & 1.83 & -.36 & -1.00 \\
\hline WTC6 & 1.00 & 7.00 & 4.36 & 1.73 & -.28 & -.88 \\
\hline WTC7 & 1.00 & 7.00 & 4.51 & 1.81 & -.32 & -.83 \\
\hline WTC8 & 1.00 & 7.00 & 4.58 & 1.83 & -.40 & -.80 \\
\hline WTC9 & 1.00 & 7.00 & 4.09 & 1.90 & -.04 & -1.07 \\
\hline WTC10 & 1.00 & 7.00 & 4.00 & 1.98 & .00 & -1.16 \\
\hline Total WTC & 16.00 & 69.00 & 43.52 & 11.76 & -.05 & -.22 \\
\hline
\end{tabular}

The total mean score of the communication anxiety was 32.63. As there are ten items on a seven point scale, the highest score for this scale is 70. The same rule for interpreting L2WTC was used for communication anxiety. A total score of more than $80 \%$ of the full score, which is 56 (i.e. $70 \times 80 \%$ ) shows high level of communication anxiety; and a total score of $60 \%$ to $80 \%$ of the full score, which is between 42 and 56 , indicates moderate communication anxiety. In the present study, the mean score (32.63) was less than 42, which implies that Iranian EFL learners feel low levels of anxiety while communicating inside the classroom.

Table 2

Descriptive statistics for communication anxiety items

\begin{tabular}{|c|c|c|c|c|c|c|}
\hline Items & Min & Max & $\mathrm{M}$ & $\mathrm{SD}$ & Skewness & Kurtosis \\
\hline CA1 & 1.00 & 7.00 & 2.73 & 1.59 & .69 & -.30 \\
\hline CA 2 & 1.00 & 7.00 & 2.74 & 1.81 & .69 & -.62 \\
\hline CA 3 & 1.00 & 7.00 & 3.72 & 1.91 & -.09 & -1.20 \\
\hline CA 4 & 1.00 & 7.00 & 3.02 & 1.84 & .41 & -1.11 \\
\hline CA 5 & 1.00 & 7.00 & 2.98 & 1.55 & .55 & -.12 \\
\hline CA 6 & 1.00 & 7.00 & 3.32 & 1.86 & .26 & -.98 \\
\hline $\mathrm{CA} 7$ & 1.00 & 7.00 & 2.41 & 1.39 & -.78 & .79 \\
\hline CA 8 & 1.00 & 6.00 & 2.25 & 1.39 & .81 & -.38 \\
\hline CA 9 & 1.00 & 7.00 & 3.14 & 1.89 & .53 & -.84 \\
\hline CA 10 & 1.00 & 7.00 & 3.38 & 1.76 & .23 & -.90 \\
\hline Total CA & 12.00 & 57.00 & 32.63 & 9.84 & .15 & .35 \\
\hline
\end{tabular}

Descriptive statistics for perceived communication competence (PCC) is shown in Table 3. There were six can-do questions ranging from $0 \%$ to $100 \%$. All the scores were normally distributed within the range of \pm 2.0 . Iranian EFL learners had the highest level of perceived communication competence when giving a short 
Ghonsooly, B., Hosseini Fatemi, A., \& Khajavy, G. H.

self-introduction without notes in English to the class (item PCC5), and the least level of perceived communication competence when doing a role-play standing in front of the class in English (Item PCC2).

Table 3

Descriptive statistics for perceived communication competence items

\begin{tabular}{|c|c|c|c|c|c|c|}
\hline Items & Min & Max & M & SD & Skewness & Kurtosis \\
\hline PCC1 & 10.00 & 100.00 & 71.12 & 22.94 & -.45 & -.54 \\
\hline PCC2 & 10.00 & 100.00 & 64.07 & 24.87 & -.11 & -1.12 \\
\hline PCC3 & 10.00 & 100.00 & 65.50 & 25.83 & -.27 & -.97 \\
\hline PCC4 & 10.00 & 100.00 & 73.06 & 24.18 & -.66 & -.62 \\
\hline PCC5 & 20.00 & 100.00 & 83.92 & 20.19 & -1.11 & .08 \\
\hline PCC6 & 20.00 & 100.00 & 75.62 & 21.71 & -.59 & -.70 \\
\hline Total PCC & 150 & 600 & 433.31 & 117.51 & -.74 & .35 \\
\hline
\end{tabular}

The total mean score of the perceived communication confidence was 433.31. As there are six items on an eleven can-do scale, the highest score for this scale is 600 . A total score of more than $80 \%$ of the full score, which is 480 (i.e. $600 \times 80 \%$ ) shows high level of perceived communication confidence; and a total score of $60 \%$ to $80 \%$ of the full score, which is between 360 and 480 , indicates moderate perceived communication confidence. In the present study, the mean score (433.31) was between 360 and 480, suggesting that Iranian EFL learners perceived themselves moderately confident to communicate in English inside the classroom. Pearson product moment correlation formula was also used to examine the correlations between WTC in English, communication confidence, and classroom environment. Results are shown in Table.

Table 4

Correlations between the variables

\begin{tabular}{lllllll}
\hline & 1 & 2 & 3 & 4 & 5 & 6 \\
\hline 1.WTC & 1.00 & & & & & \\
2.PCC & $.21^{* *}$ & 1.00 & & & \\
3.Anxiety & $-.16^{*}$ & $-.51^{* *}$ & 1.00 & & & \\
4.Teacher & $.15^{*}$ & .09 & $-.18^{*}$ & 1.00 & & \\
5.Student & $.17^{*}$ & $.19 * *$ & $-.27^{* *}$ & $.34 * *$ & 1.00 & $.32 * *$ \\
6.Task & $.29 * *$ & .06 & $-.15^{*}$ & $.46^{* *}$ & .00 \\
\hline
\end{tabular}

As can be seen in Table 4, WTC in English is positively correlated with PCC (r= .21, p<.01), teacher support $(\mathrm{r}=.15, \mathrm{p}<.05)$, student cohesiveness $(\mathrm{r}=.17, \mathrm{p}<.05)$, and task orientation $(\mathrm{r}=.29, \mathrm{p}<.01)$, and negatively with communication anxiety $(\mathrm{r}=-.16, \mathrm{p}<.05)$. Also, PCC is positively correlated with student cohesiveness $(\mathrm{r}=.19, \mathrm{p}<.01)$, and negatively with communication anxiety $(\mathrm{r}=-.51, \mathrm{p}<.01)$. Moreover, communication anxiety was negatively correlated with teacher support $(\mathrm{r}=-.18, \mathrm{p}<.05)$, student cohesiveness $(\mathrm{r}=-.27, \mathrm{p}<.01)$, and task orientation $(\mathrm{r}=-.15, \mathrm{p}<.05)$.

\section{Discussion}

Descriptive statistics indicated that Iranian EFL learners' level of WTC was 43.52 out of 70. Based on the norms represented in section 4.2, Iranian EFL learners are moderately willing to communicate in English classrooms. The reasons for a moderate level of WTC in Iranian context may be due to two facts. First, Iranian English major university students do not need a good command of English speaking proficiency to pass their exams. Except for two courses (conversation and oral reproduction of story courses), students are required to write their answers for their exams. Therefore, academic achievement is not much dependent on good speaking proficiency, and many students may be silent during the class time, because they can pass the exams with good 
scores regardless of good English speaking ability. Second, as most of the classes in Iranian context are teacher-based and social communicative needs are not much emphasized, they may find no opportunity to speak in their classes.

Among different classroom opportunities for speaking English, Iranian EFL learners were most willing to ask the teacher in English to repeat what he or she just said in English because they did not understand and were least willing to do a role-play standing in front of the class in English. This implies that because passing the courses and obtaining good marks are of great importance for academic achievement of the students, they ask their teachers in English to repeat what they did not understand. Results also suggest that Iranian EFL learners are least willing to engage in role-play activities (either in front of the class or at their desk with their peers). It can also be related to the importance of academic achievement in which exams are mostly in written form, and therefore, role-playing seems irrelevant. This finding is in line with Peng (2009) who found similar results in China.

As mentioned before, communication confidence is composed of perceived communicative competence and lack of anxiety. Iranian EFL learners perceived themselves moderately confident to communicate in English inside the classroom (433.31 out of 600). They had the highest level of perceived communicative competence when giving a short self-introduction without notes in English to the class, and the least level of perceived communication competence when doing a role-play standing in front of the class in English. Giving a brief self-introduction to the class seems the easiest communicative task for Iranian EFL learners. As all of the participants in the resent study had competitively passed the university entrance exam to enter the university for studying English language, it is not strange that they perceived themselves most able to briefly self-introduce themselves. Interestingly enough, they again selected role-paying as the least perceived communicative task. This finding confirms the result of the previous section in which the students were less willing to do a role-play. All of these findings shed light on the nature of role-playing in Iranian EFL context which do not seem to be attractive and interesting for students.

Results of the descriptive statistics indicated that Iranian EFL learners feel low levels of anxiety while communicating inside the classroom (32.63 out of 70). They experienced the most communication anxiety when they have to speak English without preparation in class and they felt the least anxiety when speaking English in the classroom. The second most anxiety provoking situation was "I get nervous when the language teacher asks questions which I have not prepared in advance". These two items indicate the importance of preparation before speaking in English classrooms. If students feel they are not prepared enough to speak English in the classroom, they feel anxious in the classroom. As the results of the descriptive study confirmed, Iranian EFL learners feel low levels of anxiety. This finding was reflected in the least anxiety-provoking situation" speaking English in the classroom" which is a general question asking about feeling anxious in the language classroom.

Correlational analyses also indicated that classroom environment is positively related to WTC in English. It implies that when teachers support the students, tasks are interesting and challenging, and the students help each other in the classroom, students are more willing to communicate in English inside the classroom. This finding is in line with Peng's (2009). Results also indicated that WTC is negatively correlated with communication anxiety, and positively with perceived communicative competence. This finding is also consistent with previous studies in different settings (Ghonsooly et al, 2012; Peng \& Woodrow, 2010; Kim, 2004; Yashima, 2002).

There are some pedagogical implications in the present study. As classroom environment was positively correlated with WTC in English, it can be said that providing a highly supportive classroom environment would help language learners to be more willing to communicate in their English classrooms. Teachers should provide a relaxing environment in the classroom where students help each other and the tasks are challenging and interesting. Anxiety was also negatively correlated with WTC which implies that by reducing anxiety, teachers can increase students' WTC in English. Moreover, anxiety was negatively correlated with classroom environment. Therefore, if teachers provide students with an encouraging classroom environment, students feel 
less anxious to communicate in English inside the classroom. Also, some relaxation techniques can be taught to students in order to decrease their anxiety level.

In the present study, only speaking aspect of WTC was examined. Further research can explore WTC with regard to other three modes of communication. Also, results of this study are generalizable to participants of the current study with certainty; further generalizations should be done with care.

\section{References}

Aida, Y. (1994). Examination of Horwitz, Horwitz, and Cope's construct of foreign language anxiety: The case of students of Japanese. The Modern Language Journal, 78, 155-168. http://dx.doi.org/10.1111/j.1540-4781.1994.tb02026.x

Bronfenbrenner, U. (1979). The ecology of human development. Cambridge, MA: Harvard University Press.

Burgoon, J. K. (1976). The unwillingness-to-communicate scale: Development and validation. Communication Monographs, 43, 60-69. http://dx.doi.org/10.1080/03637757609375916

Cetinkaya, Y. B. (2005). Turkish college students' willingness to communicate in English as a foreign language. Unpublished doctoral dissertation, Ohio State University, Columbus, Ohio.

Charos, C. (1994). Personality and individual differences as predictors of second language communication: A causal analysis. Unpublished honors thesis, University of Ottawa, Canada.

Clément, R. (1980). Ethnicity, contact, and communicative competence in a second language. In H. Giles, W.P. Robinson, \& P. M. Smith (Eds.) Language: Social psychological perspectives. (pp. 147-154). New York: Pergamon. http://dx.doi.org/10.1177/0261927X8600500403

Clément, R. (1986). Second language proficiency and acculturation: An investigation of the effects of language status and individual characteristics. Journal of Language and Social Psychology, 5, 271-290.

Dorman, J. P., Fisher, D. L., \& Waldrip, B. G. (2006). Learning environments, attitudes, efficacy and perceptions of assessment: A LISREL analysis. In D. L. Fisher \& M. S. Khine (Eds.), Contemporary approaches to research on learning environments (pp. 1-28). Singapore: World Scientific. http://dx.doi.org/10.1142/9789812774651_0001

Fraser, B. J., Fisher, D. L., \& McRobbie, C. J. (1996). Development, validation, and use of personal and class forms of a new classroom environment instrument. Paper presented at the Annual Meeting of the American Educational Research Association, New York.

Ghonsooly, B., Khajavy, G.H., \& Asadpour, S. F. (2012). Willingness to communicate in English among Iranian non-English major university students. Journal of Language and Social Psychology, 31, 197-211. http://dx.doi.org/10.1177/0261927X12438538

Horwitz, E. K. (2001). Language anxiety and achievement. Annual Review of Applied Linguistics, 21, 112-126. http://dx.doi.org/10.1017/S0267190501000071

Kim, S. J. (2004). Exploring Willingness to Communicate (WTC) in English among Korean EFL (English as a Foreign Language) Students in Korea: WTC as a Predictor of Success in Second Language Acquisition. Unpublished Doctoral Dissertation, Columbus: Ohio State University.

Liu, M., \& Jackson, J. (2008). An exploration of Chinese EFL learners' unwillingness to communicate and foreign language anxiety. The Modern Language Journal, 92, 71-86. http://dx.doi.org/10.1111/j.1540-4781.2008.00687.x

MacIntyre, P. (1994). Variables underlying willingness to communicate: A casual analysis. Communication Research Reports, 11, 135-142. http://dx.doi.org/10.1080/08824099409359951

MacIntyre, P. D. (1999). Language anxiety: A review of literature for language teachers. In D. J. Young (Ed.), Affect in foreign language and second language learning (pp. 24-43). New York: Mc Graw Hill Companies.

MacIntyre, P. D. (2002). Motivation, anxiety and emotion in second language acquisition. In P. Robinson (Ed.), Individual differences and instructed language learning (pp. 45-68). Amsterdam: John Benjamins Publishing Company. 
Relationships between willingness to communicate in English, confidence, and classroom environment

MacIntyre, P. D., \& Charos, C. (1996). Personality, attitudes, and affect as predictors of second language communication. Journal of Language and Social Psychology, 15, 3-26. http://dx.doi.org/10.1177/0261927X960151001

MacIntyre, P. D., Clément, R., Dörnyei, Z., \& Noels, K. A. (1998). Conceptualizing willingness to communicate in a L2: A situational model of L2 confidence and affiliation. The Modern Language Journal, 82, 545-562. http://dx.doi.org/10.1111/j.1540-4781.1998.tb05543.x

MacIntyre, P. D., \& Gardner, R. C. (1991). Methods and results in the study of anxiety and language learning: A review of the literature. Language Learning, 41, 85-115. http://dx.doi.org/10.1111/j.1467-1770.1991.tb00677.x

MacIntyre, P. D., Noels, K. A., \& Clément, R. (1997). Biases in self-ratings of second language proficiency: The role of language anxiety. Language Learning, 47, 265- 287. http://dx.doi.org/10.1111/0023-8333.81997008

Mahmoodzadeh, M. (2013). Investigating foreign language anxiety in Iranian classrooms: The effect of gender. International Journal of Research Studies in Language Learning, 2, 61-70. http://dx.doi.org/10.5861/ijrsll.2012.109

McCroskey, J. C., \& Baer, J. E. (1985, November).Willingness to communicate: The construct and its measurement. Paper presented at the annual meeting of the Speech Communication Association, Denver, CO: (ERIC Document Reproduction Service No. Ed 265-604).

McCroskey, J. C., \& Richmond, V. P. (1987). Willingness to communicate and interpersonal communication. In J. C. McCroskey \& J. A. Daly (Eds.), Personality and interpersonal communication (pp. 129-159). Newbury Park, CA: Sage.

Mortensen, C. D., Arnston, P. H., \& Lustig, M. (1977). The measurement of verbal predispositions: Scale development and application. Human Communication Research, 3, 146-158. http://dx.doi.org/10.1111/j.1468-2958.1977.tb00513.x

Peng, J. (2009). Exploring willingness to communicate (WTC) in English in Chinese EFL university classrooms: A mixed methods approach. Unpublished doctoral dissertation, Sydney University, Sydney.

Peng, J., \& Woodrow, L. (2010). Willingness to communicate in English: A Model in the Chinese EFL classroom context. Language Learning, 60, 834-876. http://dx.doi.org/10.1111/j.1467-9922.2010.00576.x

Salahshoor, F. (1999). A Genre-based approach to EFL academic literacy: The case of Iran. Unpublished PhD dissertation, University of Essex, Essex: UK.

Sallinen-Kuparinen, A., McCroskey, J. C., \& Richmond, V. (1991). Willingness to communicate, communication apprehension, introversion, and self-reported communication competence: Finnish and American comparisons. Communication Research Reports, 8, 55-64. http://dx.doi.org/10.1080/08824099109359876

Tóth, Z. (2007). Predictors of foreign-language anxiety: Examining the relationship between anxiety and other individual learner variables. In J. Horváth \& M. Nikolov (Eds.), Empirical studies in English applied linguistics (pp. 123-148). Pécs: Lingua Franca Csoport.

Weaver, C. (2005). Using the Rasch model to develop a measure of second language learners' willingness to communicate within a language classroom. Journal of Applied Measurement, 6(4), 396-415.

Williams, M., \& Burden, R. (1997). Psychology for language teachers: A social constructivist approach. Cambridge: Cambridge University Press.

Yashima, T., Zenuk-Nishide L., \& Shimizu, K. (2004). The influence of attitudes and affect on willingness to communicate and second language communication. Language Learning, 54, 119-152. http://dx.doi.org/10.1111/j.1467-9922.2004.00250.x

Young, D. (1991). Creating a low-anxiety classroom environment: What does language anxiety research suggest? Modern Language Journal, 75, 426-439. http://dx.doi.org/10.1111/j.1540-4781.1991.tb05378.x 
Ghonsooly, B., Hosseini Fatemi, A., \& Khajavy, G. H. 